AJChE 2020, Vol. 20, No. 2, $174-183$

\title{
Heating Characteristics of Palm Oil Industry Solid Waste and Plastic Waste Mixture using a Microwave Oven
}

Novi Caroko*,1,2

Harwin Saptoadi ${ }^{1}$

Tri Agung Rohmat ${ }^{1}$

1 Dept. of Mechanical and Industrial Engineering, Faculty of Engineering, Universitas Gadjah Mada, Indonesia

2 Dept. of Mechanical Engineering, Faculty of Engineering, Universitas Muhammadiyah Yogyakarta, Indonesia

*e-mail: novicaroko@umy.ac.id

A microwave thermogravimetric analyzer was used to measure the characteristics of a mixture of palm oil solid waste (fiber, shell, and empty fruit bunch) and polyethylene terephthalate (PET). In the study, the range of palm oil solid waste composition ratios to PET used was 100:0, 75:25, 50:50, 25:75, and 0:100 (by weight). The study included the influence of the quality of raw material on the heating process. The mixture of palm oil solid waste (fiber, shell, and empty fruit bunch) and PET proved to impact the heating rate, mass-loss rate, and energy consumption. Based on the observation, empty fruit bunch-PET mixture had the highest heating rate (average $1.5039^{\circ} \mathrm{C} / \mathrm{s}$ ) than shell (average $0.6058^{\circ} \mathrm{C} / \mathrm{s}$ ), and fiber $\left(0.9119^{\circ} \mathrm{C} / \mathrm{s}\right.$ ) and also had the highest mass-loss rate (average $0.0253 \mathrm{~g} / \mathrm{s}$ ). The highest biomass (shell, empty fruit bunch, and fiber) and PET composition ratio give the highest rate of heating rate (average $1.8264^{\circ} \mathrm{C} / \mathrm{s}$ ) and mass-loss rate (average $0.02875 \mathrm{~g} / \mathrm{s}$ ). In addition, the increasing ratio of fixed carbon and material density will impact the increasing heating rate and mass-loss rate and decrease energy consumption. Therefore, fixed carbon and material gaps significantly affect the heating rate.

Keywords: energy consumption, heating process, heating rate, mass-loss rate, microwave oven.

\section{INTRODUCTION}

Renewable energy usage is believed to replace fossil fuels because of high energy demand throughout the world, unstable, uncertain sources, and it is feared that global climate change will occur (Owusu and Asumadu-Sarkodie 2016). There are abundant renewable energy sources in the world, such as geothermal, solar, wind, 
water, and biomass (BPPT 2014, Panwar et al. 2011). Palm oil is the readiest renewable energy source and has several advantages as a partial replacement for future fossil energy. One of the advantages is the abundance of sources of palm oil in Indonesia. Nowadays, Indonesia is one of the world's largest palm oil producers (BPPT 2014, Ditjenbun 2018). In 2016, about 12 million hectares of oil palm plantation's production capacity was about 33 million tons (Ditjenbun 2018, Huang et al. 2016). Also, as Indonesia's agricultural products, palm oil is essential for economic sectors. The United States Department of Agriculture (Garrett and Arif 2019) explains that in 2019, palm oil products are estimated to reach 4.3 million tons, increased by 1.5 million tons from 2018, and most of the product was produced by Indonesia.

The increase in palm oil production has an impact on the increase in palm oil waste production. Palm oil waste has several types (Fig.1), including palm kernel shells (PKS), palm fiber (Mesocarp Fiber/MF), and Empty Fruit Bunch (EFB) (Hambali and Rivai 2017).

In addition to palm oil industrial waste, there is municipal waste such as plastic waste. More than 300 million tons of plastic, including polyethylene terephthalate (PET), polypropylene (PP), polystyrene (PS), low-density polyethylene (LDPE), and high-density polyethylene (HDPE) (Anuar Sharuddin et al. 2016, Miandad et al. 2017) are produced every year with an increase in plastic usage of around 4\% per year (Anuar Sharuddin et al. 2016). The plastic products and packaging raise several environmental problems, such as environmental pollution caused by compounds that are not integrated and cannot be recycled. The increasing demand for plastics will cause growth in waste accumulation every year.

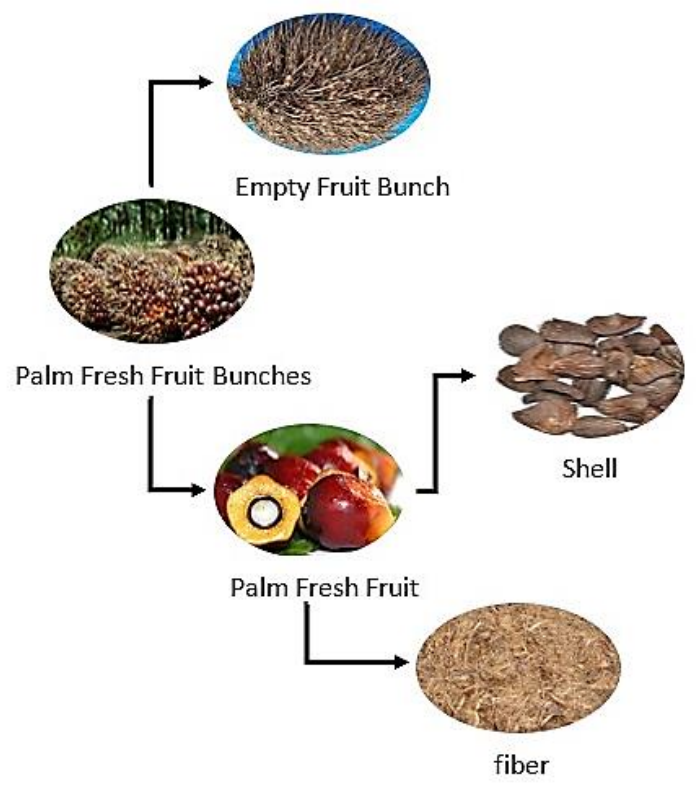

Fig 1. The wastes generated from oil palm trees

PET has an ester group so that it can be processed using chemical recycling methods. To date, several chemical recycling methods for PET have been used, such as hydrolysis glycolysis, methanolysis, aminolysis, etc. The phenomenon in PET waste treatment is the length of reaction time and the amount of energy required (Beneš et al. 2013).

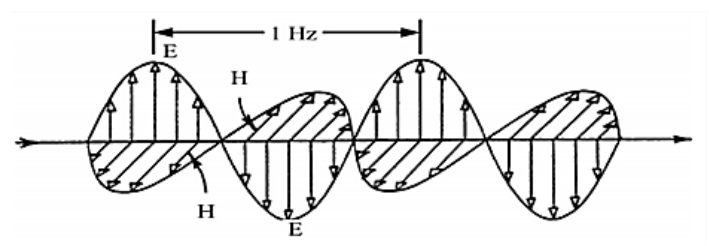

Fig 2. Electrical (E) and Magnetic $(H)$ waves in microwaves (Motasemi and Afzal 2013)

Since the 19th century, the usage of microwaves as thermal processing has 
176 Heating Characteristics of Palm Oil Industry Solid Waste and Plastic Waste Mixture using a Microwave Oven

been documented. Microwaves are characterized as electromagnetic waves comprising electrical and magnetic waves, as illustrated in figure 2.

Microwave reactors operate at standard 2.45 GHz microwave frequency and 12.25 $\mathrm{cm}$ microwave wavelength, whereas microwave irradiation works between 0.3$300 \mathrm{GHz}$ and between 0.01-1 m. Research, industries, and hospital require microwaves with a frequency range between 915 and $2450 \mathrm{MHz}$ [10]. Figure 3 displays the microwave regions of the electromagnetic spectrum.

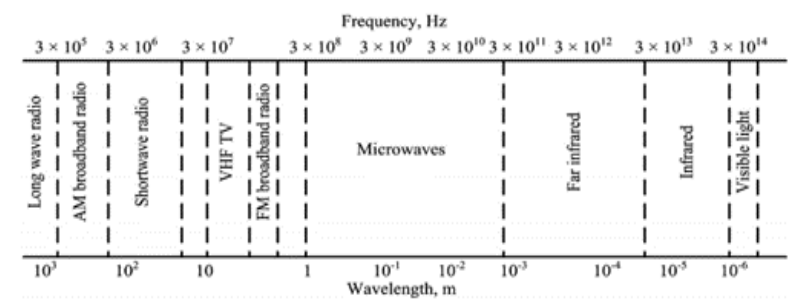

Fig. 3. The electromagnetic spectrum (Motasemi and Afzal 2013)

Microwave energy penetrates the materials in such a way that the heat produced corresponds to the material volume. The microwave, used as a heating device, allows heat to reach the center of the materials.

Fast processing, accelerated cooling, selective heating, uniform heating, no contact between microwave sources and raw materials, and heating the desired substance only are the benefits of using the microwave as thermal processing (del Mundo et al. 2018).

The microwave receptors are calibrated to the type and quantity of the substance being heated. Some types of receptors reacted completely like carbon, but other types did not react entirely like silicon carbide (Chemat and Poux 2001). Receptors (absorbers) detect microwave irradiation and transform it into heat. Since it reduces the energy consumption level and period of heating, this system is considered efficient. The microwave use include drying, heating, synthesizing, and extracting.

The processing of oil palm industry solid waste and plastic waste is not yet optimal, which has led to treating waste to be used as an energy source. Heat treatment using a microwave is one method to improve the material quality so that it has added value and efficiency in the use of energy. Knowledge of the microwave heating characteristics is essential for obtaining the optimal heating condition using a microwave oven.

Nowadays, there is increased interest in research investigating biomass characteristics. For example, Susanto and Syamsuriputra (2004) used oil palm empty bunches to produce ethanol by utilizing hydrolyzed pentose. The study observation use (a) acid hydrolysis at a mild condition, (b) detoxification of hydrolysis containing pentose, (c) cell growth, and (d) fermentation to produce ethanol. In addition, Halim et al. (2019) utilize torrefied palm mesocarp fiber (PMF) to study the effect of gasification temperature on synthesis gas production and gasification performance. This study indicates that the percentage of cold gas efficiency (CGE) reaches a maximum of $67 \%$ for raw $\mathrm{PMF}$, while carbon conversion (CC) is $85.6 \%$ for torrefied $\mathrm{PMF}$ at a gasification temperature of $900^{\circ} \mathrm{C}$.

On the other hand, solid waste palm oil has high fixed carbon contents to help the plastic heating process. The heating process is one of the waste treatment 
methods considered decent to be developed to change waste into numerous products with larger economic values, such as refuse-derived fuel (RDF). Researches on the effect of the type of material (density and fixed carbon content) and microwave power on heating characteristics are still very limited. The present study aims to determine the heating characteristics using raw materials, a mixture of biomass (shells, fiber, and empty fruit bunches) and PET, at a microwave power of 800 Watts.

\section{MATERIALS AND METHODS}

\section{Material}

The present work has made use of raw materials (fibers, shells, and empty fruit bunch) collected from a palm oil industry in Riau, Indonesia, examined using the ASTM D7582-12. The drying process of all the biomass (fiber, shell, and empty bunch), PET, and material absorber feedstocks was conducted at $105^{\circ} \mathrm{C}$ for two hours. Table 1 presents the result of oil palm solid waste feedstocks and polyethylene terephthalate compositions analysis.

The dried materials were then ground into a 1-2 $\mathrm{mm}$ particle size. Material absorbers caught microwave irradiation and transferred it to heat. Some types of receptors reacted entirely like carbon, but other types did not respond entirely like silicon carbide (Filly et al. 2014).

The absorber used was coconut shell charcoal (available in the market in Yogyakarta, Indonesia), adjusted to the quantity and type of the heated material. The composition ratio by weight between the biomass (shell, fiber, and empty fruit bunch) and PET was 100:0, 75:25, 50:50, 25:75, and 0:100.

Each experiment was done using approximately $30 \mathrm{~g}$ of biomass mixes, PET, and material absorber. All variance used $50 \%$ absorbing material that mixed before tested. The holocellulose, alpha-cellulose, and lignin tests utilized a standard gravimetric approach for levels. Meanwhile, alpha-cellulose the used chloric acid modification method approach.

Table 1. Oil palm solid waste feedstocks and polyethylene terephthalate compositions.

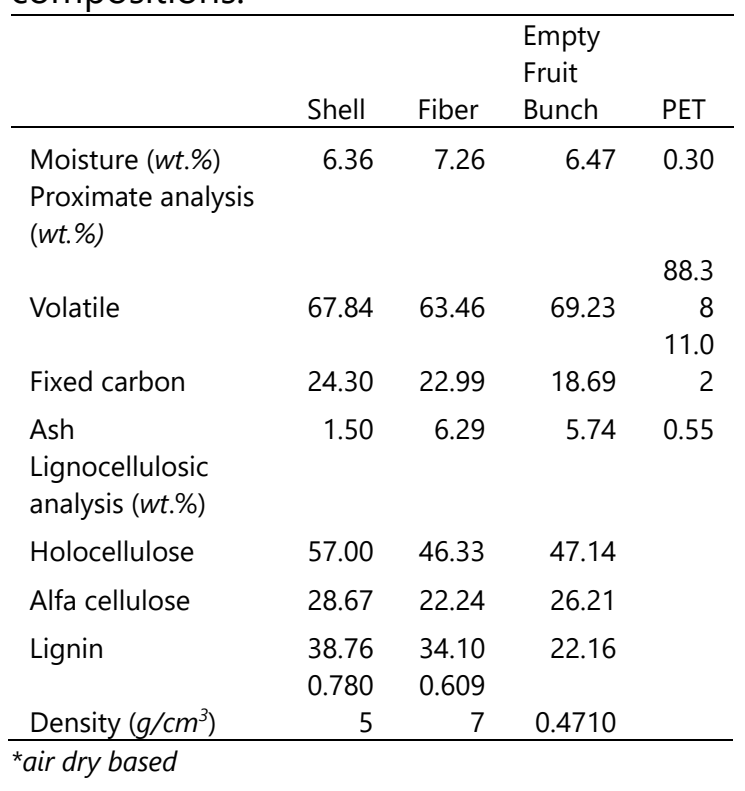

\section{Experimental Apparatus and Procedures}

The experiment was conducted using the Electrolux EMM2308X microwave oven operated at microwaves of $2.45 \mathrm{GHz}$ and power of $800 \mathrm{~W}$ on which an electronic balance (Precision: $0.0001 \mathrm{~g}$ ) was placed. The temperature and weight data were recorded throughout the experiment using the data acquisition system. The study used a Pyrex reactor with a size of $300 \mathrm{~mm}$ and $100 \mathrm{~mm}$ ID. The sample was put in $50 \mathrm{ml}$ 
178 Heating Characteristics of Palm Oil Industry Solid Waste and Plastic Waste Mixture using a Microwave Oven

crucible Pyrex and heated to reach $105^{\circ} \mathrm{C}$.

Figure 4(a) displays the schematic diagram of the system.

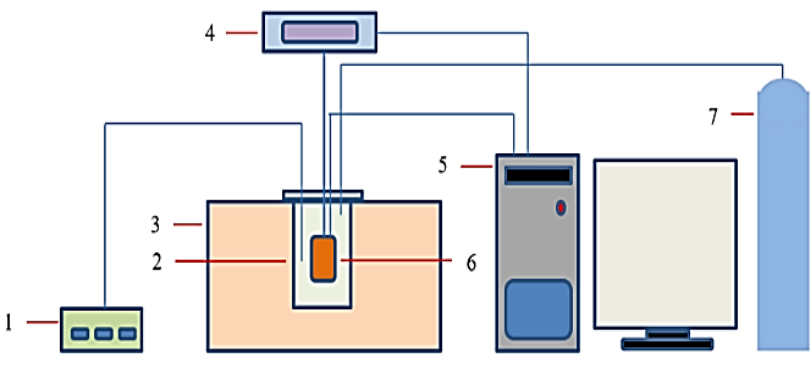

1.Temperature controller

2. Transparent glass reactor

3. Microwave oven

4. Digital precision scale

5. Data acquisition system

6. Sample container

7. $\mathrm{N}_{2}$ bottle

(a)

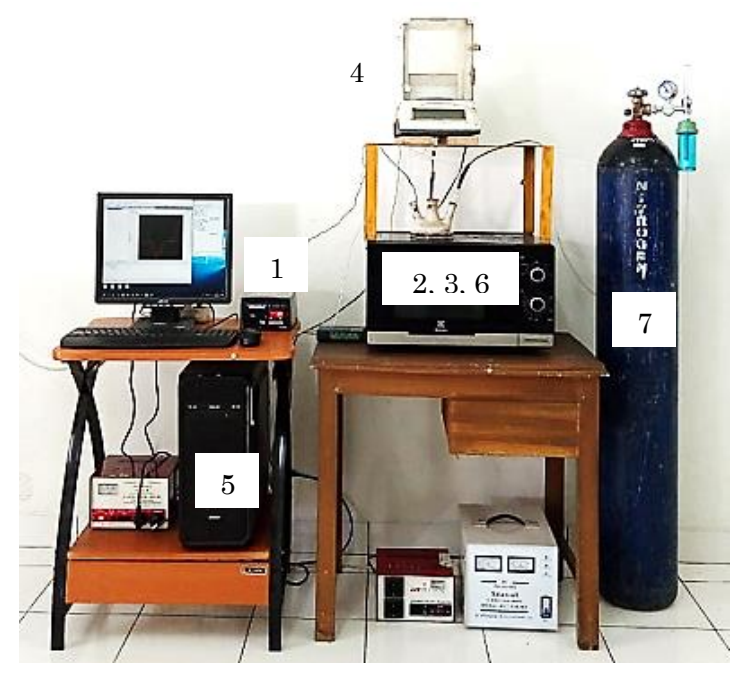

(b)

Fig. 4. Schematic (a) and pictorial view (b) of types of Microwave Thermogravimetric Analyzers.

\section{Thermogravimetric analysis}

The mass of the mixture of biomass (shell, empty fruit bunch, and fiber) and PET was measured over time as the temperature changes for each experiment. Approximately $30 \mathrm{~g}$ of the mixture was placed in a Pyrex container and was heated to $105^{\circ} \mathrm{C}$ at $250 \mathrm{ml} / \mathrm{min} \mathrm{N}_{2}$ flow rate. The composition ratio between biomass (shell, empty fruit bunch, and fiber) and PET powder was 100:0, 75:25, 50:50, 25:75, and 0:100.

During testing, the time required to reach a temperature of $105^{\circ} \mathrm{C}\left(\mathrm{t}_{\mathrm{f}}\right)$ was recorded, along with the amount of mass $\left(\mathrm{M}_{\mathrm{f}}\right)$. From those testing data, the heating rate and mass-loss rate were calculated using Eq. (1) and Eq. (2)

$$
\begin{aligned}
& H R=\frac{\left(T_{f}-T_{0}\right)}{\left(t_{f}-t_{e}\right)} \\
& M L R=\frac{\left(M_{f}-M_{0}\right)}{\left(t_{f}-t_{0}\right)}
\end{aligned}
$$

Where $T_{0}$ is initial temperature; $t_{0}$ is initial time; and $M_{o}$ is initial mass.

\section{Energy Consumption}

Energy consumption is determined using a kWh meter. The recording was started at the beginning of the test until the temperature reached $105^{\circ} \mathrm{C}$.

\section{RESULTS AND DISCUSSION}

\section{Temperature profile}

Figure 5 displays the microwave heating temperature profiles of mixtures between the biomass (shell, empty fruit bunch, and fiber) and PET with compositions of $0: 100,25: 75,50: 50,75: 25$, and 100:0 at $800 \mathrm{~W}$. The results show that the empty fruit bunch is the fastest to reach $105^{\circ} \mathrm{C}$ in approximately 40 seconds compared to the others. This phenomenon corresponds that low-density materials will reach maximum temperature faster than 
high-density materials (Somerville and Jahanshahi 2015).

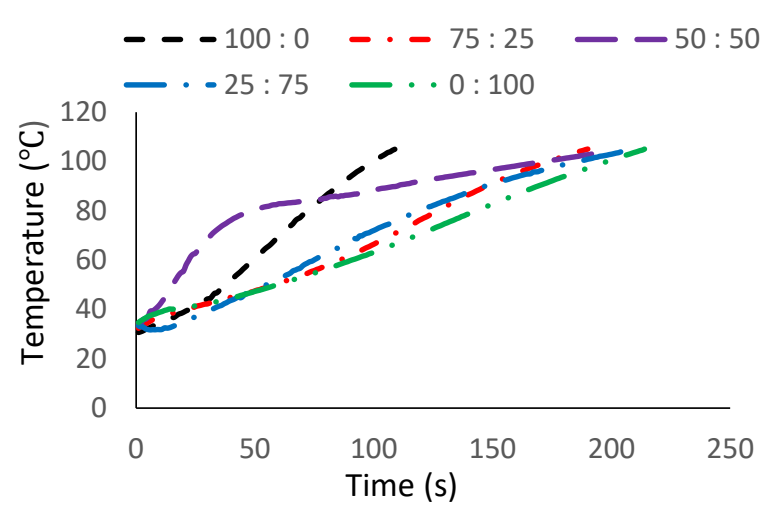

(a)

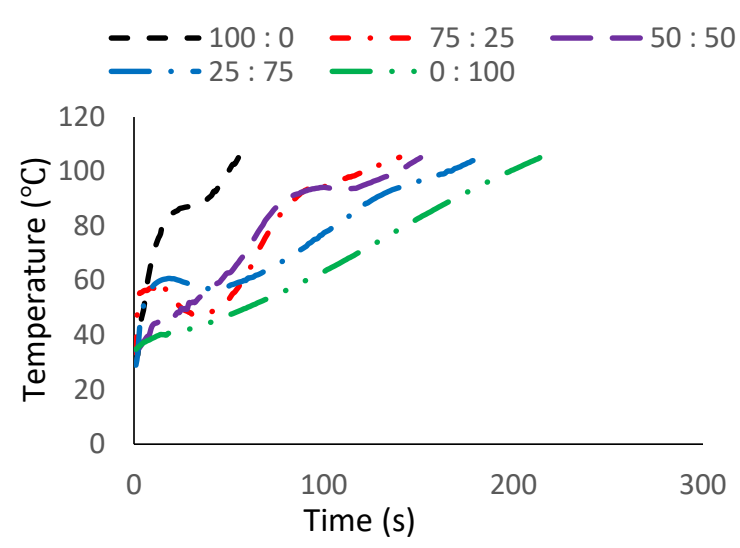

(b)

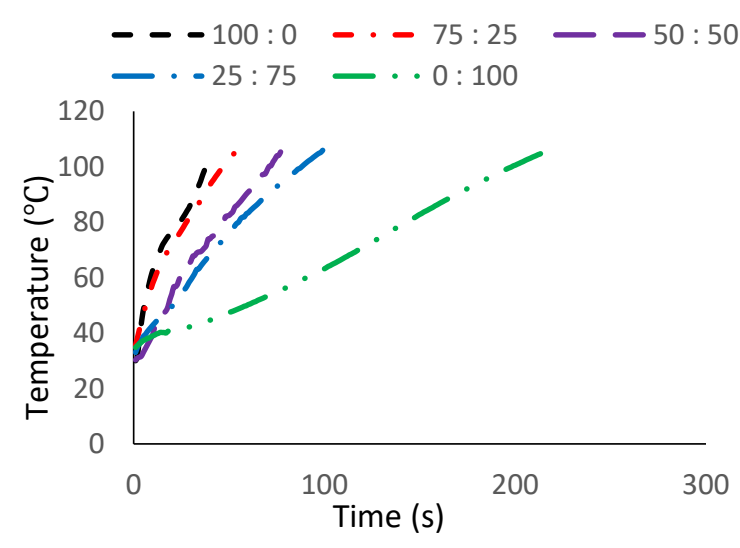

(c)

Fig. 5. Temperature profile of biomass mixes of shell (a), fiber (b) and empty bunch (c) and PET
All testing results present a similarity in temperature profile: increasing PET contents cause an increasing time to reach $105^{\circ} \mathrm{C}$. The temperature profile difference was caused by the material's capacity to absorbe microwaves (Motasemi and Afzal 2013). The addition of PET content would have an impact on decreasing the fixed carbon content on the mixture of raw material, which would ultimately reduce the material capacity in absorbing microwaves.

\section{Mass Profile}

Figure 6 shows that the thermal treatment process causes decreasing in mass. Testing on each variation shows the same mass decrease trend because the water content in biomass evaporates during the thermal treatment process (Chen et al. 2014).

Based on figures 5 and 6, it concluded that heating rate impacts mass reduction. The faster time to reach the specified temperature, the more rapid mass decreased. It is caused by the higher heatabsorption rate resulted in a more rapid water evaporation process (Barneto et al. 2009).

\section{Heating rate}

Figure 7 shows that the heating rate of all three biomass mixes (shell, empty fruit bunch, and fiber) and PET decreases, and the content of PET is increasing. The heating rate's maximum value was in the ratio of 100:0, and the minimum value was $0: 100$. Empty fruit bunch-PET mixture had the highest heating rate (average $1.5039^{\circ} \mathrm{C} / \mathrm{s}$ ) than others (average $0.6058^{\circ} \mathrm{C} / \mathrm{s}$, and $0.9118^{\circ} \mathrm{C} / \mathrm{s}$. (Amini et al. 
180 Heating Characteristics of Palm Oil Industry Solid Waste and Plastic Waste Mixture using a Microwave Oven

2018) stated that the lower density, the faster the temperature would increase. Hence, material density affects the value of the heating rate.

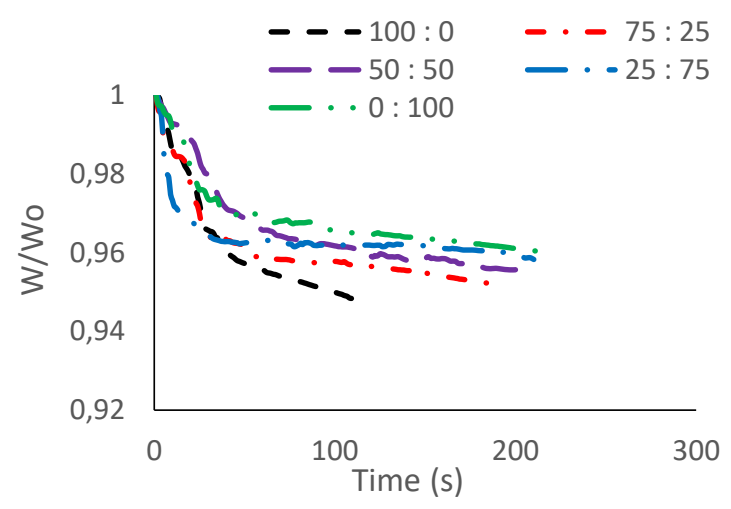

(a)

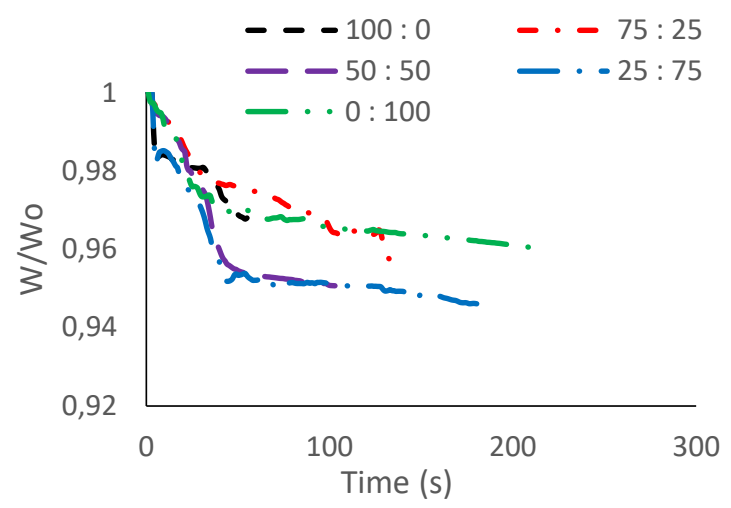

(b)

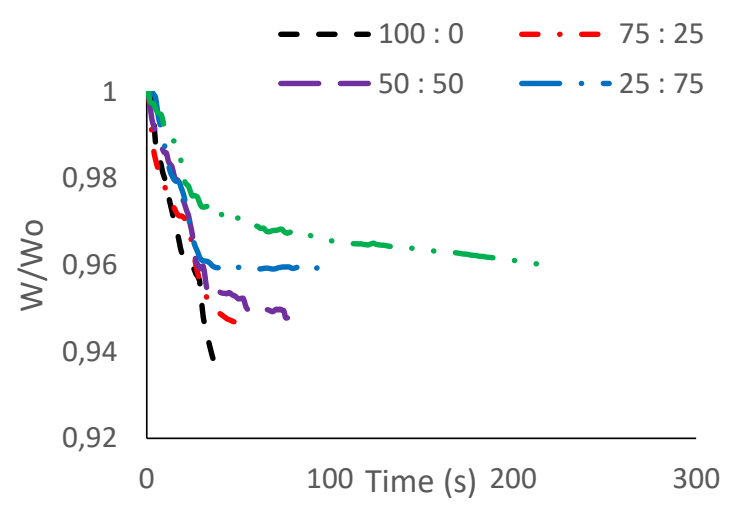

(c)

Fig. 6 Mass profile of biomass mixes of shell (a), fiber (b) and empty bunch (c) and PET
According to Namazi (A. B. Namazi et al. 2015), materials that have more gaps (less dense) will be faster to reach the maximum temperatures than materials with fewer gaps (denser). In the use of the same material, the higher fixed carbon content will have an impact on the higher heating rate. Higher fixed carbon content improved the absorption of microwaves (A. Namazi et al. 2015). Fig. 8. shows fixed carbon and material gaps significantly affect the heating rate. The increasing ratio of fixed carbon and material density will have an impact on the increasing heating rate.

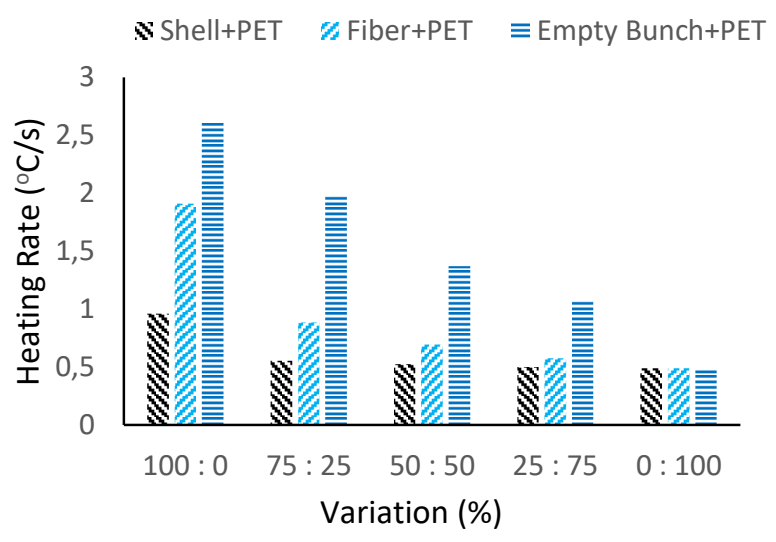

Fig. 7. Relationship between material composition and heating rate

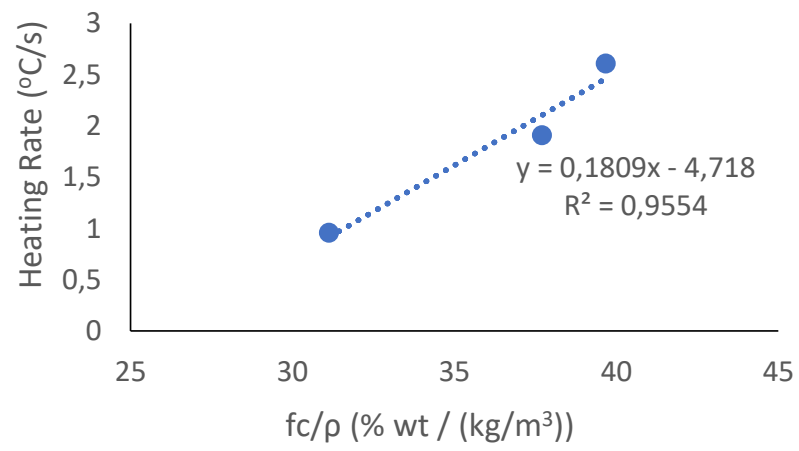

Fig. 8. Relationship between $\mathrm{fc} / \rho$ and heating rate. 


\section{Mass-loss rate}

The most mass-loss rate occurs in the empty fruit bunch (average $0.0253 \mathrm{~g} / \mathrm{s}$ ), as shown in Figure 9. It is because the empty fruit bunches have more gaps than the others, making it easier to reach $105^{\circ} \mathrm{C}$ and remove the moisture content. Heat can trigger the release of moisture content in the material into the surrounding environment (Chen et al. 2014).

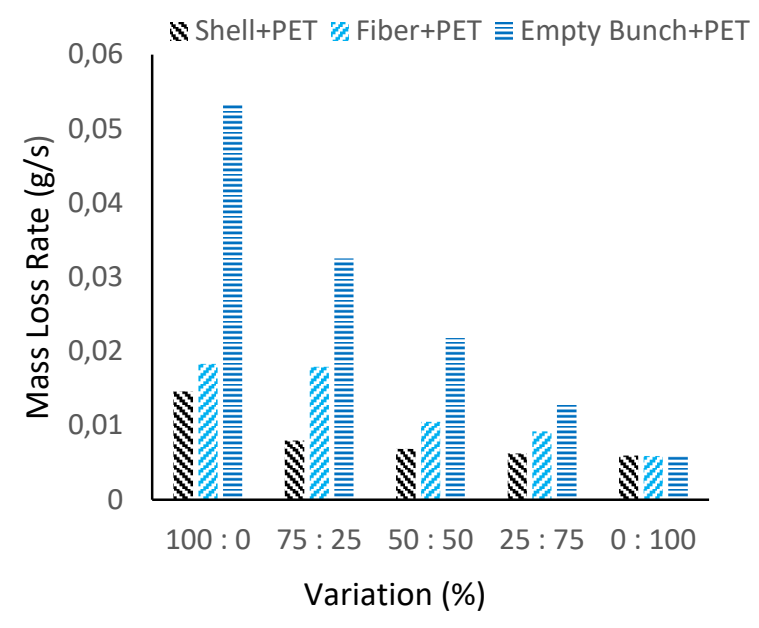

Fig. 9. Relationship between material composition and mass loss rate.

Figures 7 and 9 show that the heating rate influences the mass-loss rates-the mass-loss rate increases along with an increase in the heating rate.

Table 1 shows that the moisture content is quite similar, but figure 9 shows a different mass decrease. This phenomenon is probably caused by fixed carbon content and density ratio, that the increasing ratio of fixed carbon and material density will impact the increasing heating rate. A higher heating rate causes a higher mass-loss rate (Barneto et al., 2009).

\section{Energy Consumption}

The energy consumption in the three biomass mixes (fiber, shell, and empty fruit bunch) with PET has the same trend as shown in Figure 10. The amount of energy consumption rises by an escalating percentage of PET. Pure PET consumes the highest energy, 47.55 watt-hours, compared to other variations. The empty fruit bunch consumes the lowest energy when compared to the shell and fiber. It was probably because of the increasing ratio of fixed carbon content and material density decreased energy consumption.

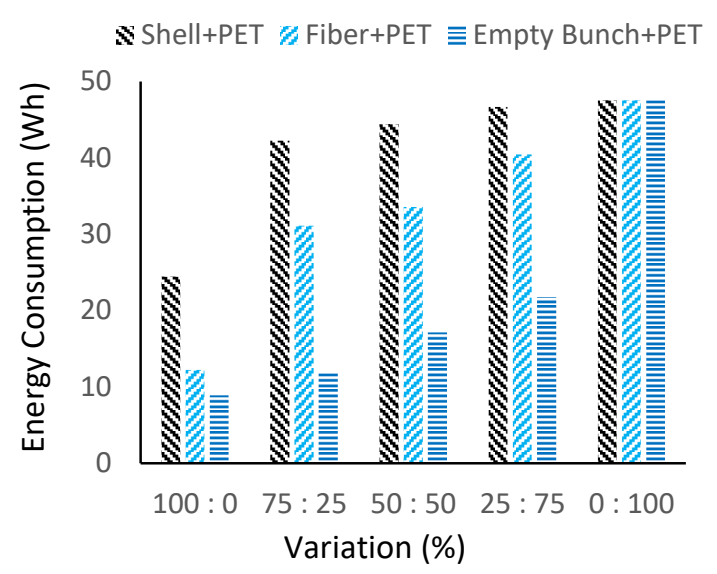

Fig. 10. Relationship between material composition and energy consumption.

\section{CONCLUSIONS}

Referring to observation, the type and composition of raw materials have a significant effect on heating rate, mass-loss rate, and energy consumption. The higher content of biomass, i.e., shell, fiber, and empty fruit bunch combined with PET, give a higher heating rate and mass-loss rate. The average heating rate in the composition of 100:0 of biomass and PET is $1.8264^{\circ} \mathrm{C} / \mathrm{s}, 75: 25$ is $1.1402^{\circ} \mathrm{C} / \mathrm{s}, 50: 50$ is 
182 Heating Characteristics of Palm Oil Industry Solid Waste and Plastic Waste Mixture using a Microwave Oven

$0.8631^{\circ} \mathrm{C} / \mathrm{s}, 25: 75$ is $0.7155^{\circ} \mathrm{C} / \mathrm{s}$, and $0: 100$ is $0.4905^{\circ} \mathrm{C} / \mathrm{s}$. In addition, the average massloss rate at the composition of $100: 0$ is $0.0287 \mathrm{~g} / \mathrm{s}, 75: 25$ is $0.0194 \mathrm{~g} / \mathrm{s}, 50: 50$ is $0.0130 \mathrm{~g} / \mathrm{s}, 25: 75$ is $0.0094 \mathrm{~g} / \mathrm{s}$, and is $0: 100$ $0.0059 \mathrm{~g} / \mathrm{s}$. Meanwhile, the higher content of biomass combined with PET gives lower energy consumption. The average energy consumption in the composition of $100: 0$ is $11.52 \mathrm{Wh}, 75: 25$ is $28.37 \mathrm{Wh}, 50: 50$ is 31.70 Wh, 25:75 is $36.30 \mathrm{Wh}$, and 0:100 is 47.55 Wh. Therefore, the increased ratio of fixed carbon content to the density of material impacts on the increase in heating rate and mass-loss rate but reduces energy consumption. So, the energy used for material heating will be optimal.

\section{REFERENCES}

1. Amini, A., Ohno, K., Maeda, T., and Kunitomo, K. (2018). "Effect of particle size and apparent density on the initial stages of temperature increase during the microwave heating of $\mathrm{Fe}_{3} \mathrm{O}_{4}$," Powder Technol., 338, 101-9.

2. Anuar Sharuddin, S. D., Abnisa, F., Wan Daud, W. M. A., and Aroua, M. K. (2016). "A review on pyrolysis of plastic wastes," Energy Convers. Manage., 115, 308-26.

3. Barneto, A. G., Carmona, J. A., Gálvez, A., and Conesa, J. A. (2009). "Effects of the composting and the heating rate on biomass gasification," Energy Fuels., 23 (2), 951-7.

4. Beneš, H., Slabá, J., Walterová, Z., and Rais, D. (2013). "Recycling of waste poly(ethylene terephthalate) with castor oil using microwave heating," Polym. Degrad. and Stab., 98/11, 223243.

5. BPPT. (2014). Pengembangan Energi untuk Mendukung Program Substitusi
BBM. (A. Sugiyono, Anindhita, and M. S. Boedoyo, Eds) Outlook Energi Indonesia., Vol. 1. Pusat Teknologi Pengembangan Sumberdaya Energi (PTPSE).

6. Chemat, F., and Poux, M. (2001). "Microwave assisted pyrolysis of urea supported on graphite under solventfree conditions," Tetrahedron Letters., 42 (22), 3693-5.

7. Chen, W. H., Kuo, P. C., Liu, S. H., and Wu, W. (2014). "Thermal characterization of oil palm fiber and eucalyptus in torrefaction," Energy, 71, 40-8.

8. Ditjenbun. (2018). 'Statistik Perkebunan Kelapa Sawit'. Retrieved from (ditjenbun.pertanian.go.id)

9. Filly, A., Fernandez, X., Minuti, M., Visinoni, F., Cravotto, G., and Chemat, F. (2014). "Solvent-free microwave extraction of essential oil from aromatic herbs: From laboratory to pilot and industrial scale," Food Chemistry., 150, 193-8.

10. Garrett, M., and Arif, R. (2019). Indonesia Oilseeds and Products Annual 2019. United States Departement of Agricalture, Foreign Agricalture Service. Retrieved from (www.fas.usda.gov)

11. Halim, N. H. A., Saleh, S., and Samad, N. A. F. A. (2019). "Effect of gasification temperature on synthesis gas production and gasification performance for raw and torrefied palm mesocarp fibre," ASEAN J. Chem. Eng., 19 (2), 120-9.

12. Hambali, E., and Rivai, M. (2017). "The Potential of Palm Oil Waste Biomass in Indonesia in 2020 and 2030," IOP Conference Series: Earth and Environmental Science., 65/1.

13. Huang, Y. F., Chiueh, P. Te, and Lo, S. L. (2016). "A review on microwave pyrolysis of lignocellulosic biomass," Sustainable Environ. Res., 26 (3), 103-9. 
14. Miandad, R., Barakat, M. A., Aburiazaiza, A. S., Rehan, M., Ismail, I. M. I., and Nizami, A. S. (2017). "Effect of plastic waste types on pyrolysis liquid oil," International Biodeterioration and Biodegradation., 119, 239-52.

15. Motasemi, F., and Afzal, M. T. (2013). "A review on the microwave-assisted pyrolysis technique," Renewable and Sustainable Energy Reviews., 28, 31730.

16. del Mundo, I. C., Cavarlez, J. M., Pe, A. M., and Roces, S. (2018). "Microwave assisted glycerolysis of neem oil," ASEAN J. Chem. Eng., 18 (1), 17-23.

17. Namazi, A., Allen, D., and Jia, C. (2015). "Microwave-assisted pyrolysis and activation of pulp mill sludge," Biomass and Bioenergy, 73.

18. Namazi, A. B., Allen, D. G., and Jia, C. Q. (2015). "Probing microwave heating of lignocellulosic biomasses," J. Anal. Appl. Pyrolysis., 112, 121-8.

19. Owusu, P. A., and Asumadu-Sarkodie, S. (2016). "A review of renewable energy sources, sustainability issues and climate change mitigation," Cogent Engineering., 3 (1).

20. Panwar, N. L., Kaushik, S. C., and Kothari, S. (2011). "Role of renewable energy sources in environmental protection: A review," Renewable and Sustainable Energy Rev., 15 (3), 151324.

21. Somerville, M., and Jahanshahi, S. (2015). "The effect of temperature and compression during pyrolysis on the density of charcoal made from Australian eucalypt wood," Renewable Energy., 80, 471-8.

22. Susanto, H., and Syamsuriputra, ali ahchmad. (2004). "Utilization of sugars in hydrolysate from oil palm empaty fruit bunches for ethanol fermentation using pichia stipitis CBS 5773," ASEAN J. Chem. Eng., 4 (2), 40-7. 